\title{
EMPLOYMENT CONDITIONS OF THE EU
}

\author{
Yaser Mueeth A Alkahtani \\ PhD Student \\ Faculty of Economics and Social Sciences, Szent IstvánUniversity \\ e-mail: zsarnoczai.sandor@gtk.szie.hu
}

\begin{abstract}
The case-study analyses the main economic conditions of the EU from points of view of emphasizing the employment, human resource management at EU-27 level. The different unemployment levels of EU member states stimulated the increasing gap between member states in GDP per capita, which was from $44 \%$ to $271 \%$ of the EU-27 average at the beginning of 2011. The unemployment rate of EU-27 increased from 6,7\% in 2000 to 8,8\% in 2010 based on the internal market conditions and influences of the world economic crisis after 2008. The human resource management has several problems in EU-27, for example the highly level of unemployment, less skilled level of employees, the unemployment rate is very highly in almost the entire EU even in case of youth under 25 year between $21,0-22,3 \%$ in $2010-2011$.
\end{abstract}

Keywords: Unemployment, Youth unemployment, Human resource management Foreign Direct Investment

\section{JEL Classification: GE11}

\section{Introduction}

The case-study analyses the main economic conditions of the EU from points of view of emphasizing employment issues, GDP per capita and AIC (Actual Individual Consumption) per capita. The world economic crisis presses mostly Mediterranean member states of EU-27, for example Italy, Greek, Spain and Portugal, where the unemployment rate was $22,3 \%$ in Spain, $21 \%$ in Greek, $22-23 \%$ in Portugal, $8,6 \%$ in Italy, but mainly in south part of Italy the unemployment rate was $20-21 \%$ in the first half of 2012 (EUROSTAT, 2012a).

In EU-27 the unemployment rate has sharply increased from level of 6,1\% since the beginning of 2008, beginning of the world economic crisis to $8,8 \%$ till the end of 2010 , after that this increased to $9,8 \%$ by the end of 2011 (ILO, 2011, EUROSTAT, 2012b; IMF, 2010a). The case study analyses the impacts of the world economic crisis on the unemployment rate in EU-27. Some experts emphasized that unemployment rate can be decreased in EU by through of increasing investment activities of foreign direct investments and supports given by foreign corporations and the EU common regional policy (see in detailed Nagy - Káposzta, 2010).

\section{Materials and Methods}

The international literature emphasized some economic conditions concerning the unemployment difficulties and possible solutions. The ILO (International Labour Organization) declared that "Fifty-five\% of the total increase in global employment between 2007 and 2010 occurred in the Developed Economies and European Union region, while the region only accounts for $15 \%$ of the world's labour force. Employment contracted by 2,2\% in 2009 and by a further $0,9 \%$ in 2010 . 
Unemployment is projected to decline slightly in 2011, but to a level that is still 15 million (over 50\%) higher than in 2007. Another manifestation of continued labour market distress is the rapid growth of par-time employment" (ILO, 2010a; ILO, 2011, p. X, in Introduction; see in detailed Káposzta et. al. 2008 in case of Romania and Bulgaria). This means that the unemployment rate sharply increased even in Mediterranean regions of the EU and other part of the highly developed world, for example USA and Canada, Japan, Australia. The other difficulty on the labour market is extending part-time employment in stead of full time employment, which can be resulted in narrowing purchasing power standard (PPS), (IMF, 2010b).

The solution for economic difficulties are to increase the jobs to decrease unemployment rate of EU-27, even decrease the youth unemployment rate, increase level of skill and knowledge for managers and employees. The increasing employment rate impacts for increasing the purchase power standard, which increases the single market demands.

The study uses the SWOT analysis based on the employment issue to discover reasons for increasing unemployment rate emphasizing the youth unemployment conditions in EU-27, after the world economic crisis and the possible solutions by stimulating investment activities. The EU-27 would like to use more private capital of EU and foreign capital from China, US and Middle East Arab countries within Foreign Direct Investment (FDI) scheme.

\section{Results and Discussion}

There are two kinds of indicator figures, namely the GDP per capita and Actual Individual Consumption (AIC) per capita, which can also determine differences among member states from point of view of consumption. The GDP per capita as a general figure concerns the all produced products and services averagely per capita, which is not real consumption in fact. But the other one, namely AIC is exact data to determine the real consumption per capita and also to reflect the real economic conditions of inhabitant based on the purchasing power standard (PPS) - (see Table-1).

Since the beginning of 2008 the AIC has moderately decreased in some less developed member states of the EU-27 in consequence of the world economic crisis, when the consumption of population decreased based on their declining PPS. These member states are for example Baltic countries, as Estonia, Lithuania, Latvia and Balkan countries, as Romania, Bulgaria, Mediterranean countries, as Spain, Cyprus, which can be mentioned, but additionally to these countries Poland had some increasing AIC, but under the average level of EU-27 after the world economic crisis, 2008. Almost in highly developed member states of the EU-27 the AIC per capita has little increased for three year -period, for example in Germany, France, Finland and Austria (see Table-1), because their economies were less influenced by the world economic crisis. Their employees are more efficient human resources in these countries and in consequence of these economic conditions they as consumers have also higher level of PPS than the other member states of the EU. Luxembourg has highest level of AIC per capita resulted by visiting workers of Luxembourg in neighbouring EU member states, who can send considerable part of their salary to their home member state. Almost member states can be influenced by the economic crisis, but these measures are very different as it can be experienced for example in data of AIC per capita in EU-27 (see Table-1).

The unemployment rate can show how the economic activities can fluctuate in EU-27, which can consequently lead to decrease output of firms and decreasing consumption trend of 
consumers based on decreasing the AIC per capita. Naturally the decreasing output of firms can decrease the export volume and by through decreasing export they can decrease the positive balance of EU-27 current account.

According to the Table-2 the data base show the first best six member states in field of less unemployment rate than the other member sates by the end of November in 2011. These member states, as Austria, where the unemployment rate was $4,0 \%$, in Netherlands $4,9 \%$, in Luxemburg 4,9\%, in Germany 5,5\%, in Malta 6,4\% and in Czech Republic 6,7\%. The except was Luxemburg, where the unemployment rate increased by $0,2 \%$ between November, 2010 and November, 2011. The unemployment rate of Luxemburg is very sensitivity from the economic fluctuation of neighbouring economies, because many of national employees of Luxemburg go abroad for obtaining jobs. These employees frequently send considerable part of their salary to their homeland, which contribute to the annual GDP of Luxemburg. In Luxemburg the economic and geographic conditions are not so favourably, which stimulate the intensive flow of national employees abroad to obtain jobs.

These six member states have very strong economic cooperation among themselves and their economies are neighbours except Malta. These member states have intensive economic growth with well managed economic conditions at levels of national economics and firms accompanying with export oriented economic strategy to make a positive balance of foreign trade and currant account balance, also stronger Euro exchange rate.

Germany can keep the moderate fast economic growth and consequently decreasing level of unemployment. Also the innovation developing process is more ambition and attractive here than other EU member states. Also the German economy has considerable positive influences on the other four neighbouring economies including Czech Republic. Czech Republic is only one of five member states, which is in the Central East European, and also the new EU member state. Manly these neighbouring member states have a strong work separation and mostly their intensive economic depend on the national conditions of Germany.

The worst conditions of other five member states in field of unemployment issue, namely Greek, where the unemployment was about estimated $22-23 \%$, in Spain $22,9 \%$, in Ireland $14,6 \%$, in Slovakia 13,5\% and in Portugal 13,2\%. In general the Mediterranean member states have the worst positions in field of unemployment rate in all EU-27. Unfortunately sometimes in South Italy the unemployment was one of the highest one in this region, and these member states, as it was equally with one of Spain. Also Italy has problem that density in Sicilian is at the middle average level of density in EU-27, which can be declared as quite high with very high unemployment level. Naturally the density became as middle average level of one, because of intensive migration from here to other parts of EU. Almost these four member states, except Slovakia, are according to the periphery regions of the EU-27.

The human resource management has several problems in EU-27, for example the high level of unemployment, less skilled level of employees, the unemployment rate is very high. In almost the entire youth unemployment under 25 year was between 21,0 in 2010 and 22,3\% in 2011. The unemployment rate of females was usually at higher level than in the case of males. Youth male were between 9,5-9,7\% and females were higher between 9,7-10,0\% in 2010-2011.

In member states of the Mediterranean region the unemployment rate was higher than in general in other parts of the EU-27 (see Table-2, Table-3). In case of Greek the unemployment rate in youth under 25 year was 58,4\% almost 60\%; this was 55,7\% in Spain, 38,2\% in Portugal, 37,8\% 
in Italy, also the average level of EU-27 was $23,5 \%$ by the end of February, 2013 (EUROSTAT, 2013). The investment activities of trans-national corporations and large companies were very less than it was needed, because considerable lack of infrastructure network, skilled workers, large distance resulting higher cost for transports, low level of density of population, which consequences on less local markets; and also the potentional producing regions are very far from the world market centres (see in detailed Nagy - Káposzta, 2010).

Table 1. Actual Individual Consumption (AIC) in PPS, in several EU member states (EU-27)

\begin{tabular}{|l|c|c|c|}
\hline \multirow{2}{*}{ Member States } & \multicolumn{3}{|c|}{ AIC per capita } \\
\cline { 2 - 4 } & 2008 & 2009 & 2010 \\
\hline EU-27 & \multicolumn{3}{|c|}{$100 \%$} \\
\hline Luxembourg & 151 & 153 & 150 \\
\hline Austria & 113 & 115 & 116 \\
\hline Germany & 113 & 116 & 117 \\
\hline Finland & 110 & 110 & 111 \\
\hline France & 111 & 113 & 95 \\
\hline Spain & 99 & 95 & 103 \\
\hline Cyprus & 108 & 101 & 57 \\
\hline Estonia & 64 & 58 & 66 \\
\hline Poland & 61 & 64 & 61 \\
\hline Lithuania & 70 & 63 & 50 \\
\hline Latvia & 59 & 50 & 45 \\
\hline Romania & 49 & 46 & 42 \\
\hline Bulgaria & 45 & 43 & \\
\hline
\end{tabular}

Source: EUROSTAT, 2011 December, Brussels 
Table (2). Seasonally adjusted unemployment rates (\%) Totals

\begin{tabular}{|c|c|c|c|c|c|c|c|c|}
\hline & $\begin{array}{l}\text { Nov } \\
2010\end{array}$ & $\begin{array}{l}\text { May } \\
2011\end{array}$ & $\begin{array}{l}\text { Jun } \\
2011\end{array}$ & $\begin{array}{c}\text { Jul } \\
2011\end{array}$ & $\begin{array}{l}\text { Aug } \\
2011\end{array}$ & $\begin{array}{c}\text { Sep } \\
2011\end{array}$ & $\begin{array}{l}\text { Oct } \\
2011\end{array}$ & $\begin{array}{l}\text { Nov } \\
2011\end{array}$ \\
\hline EA-17 & 10.0 & 10.0 & 10.0 & 10.1 & 10.1 & 10.2 & 10.3 & 10.3 \\
\hline EU-27 & 9.6 & 9.5 & 9.5 & 9.6 & 9.7 & 9.8 & 9.8 & 9.8 \\
\hline BE & 7.9 & 7.1 & 7.2 & 7.3 & 7.4 & 7.4 & 7.3 & 7.2 \\
\hline BG & 11.5 & 11.2 & 11.2 & 11.1 & 11.0 & 10.9 & 10.8 & 10.9 \\
\hline $\mathrm{CZ}$ & 6.9 & 6.9 & 6.8 & 6.7 & 6.6 & 6.5 & 6.6 & 6.7 \\
\hline DK & 7.7 & 7.5 & 7.5 & 7.4 & 7.5 & 7.6 & 7.7 & 7.8 \\
\hline DE & 6.7 & 6.0 & 5.9 & 5.9 & 5.8 & 5.7 & 5.6 & 5.5 \\
\hline EE & 14.6 & 12.7 & 12.7 & 11.3 & 11.3 & 11.3 & : & : \\
\hline IE & 14.3 & 14.2 & 14.4 & 14.7 & 14.7 & 14.6 & 14.6 & 14.6 \\
\hline EL & 14.0 & 16.9 & 17.3 & 17.9 & 18.4 & 18.8 & : & : \\
\hline ES & 20.4 & 21.0 & 21.4 & 21.8 & 22.1 & 22.5 & 22.7 & 22.9 \\
\hline FR & 9.7 & 9.6 & 9.7 & 9.7 & 9.6 & 9.6 & 9.7 & 9.8 \\
\hline IT & 8.1 & 8.2 & 8.0 & 8.0 & 7.9 & 8.3 & 8.5 & 8.6 \\
\hline $\mathrm{CY}$ & 6.0 & 7.3 & 7.4 & 7.7 & 8.0 & 8.4 & 8.8 & 9.1 \\
\hline $\mathbf{L V}$ & 17.0 & 16.1 & 16.1 & 14.8 & 14.8 & 14.8 & : & : \\
\hline LT & 17.3 & 15.6 & 15.6 & 15.3 & 15.3 & 15.3 & : & : \\
\hline $\mathbf{L U}$ & 4.7 & 4.8 & 4.8 & 4.9 & 4.9 & 5.0 & 4.8 & 4.9 \\
\hline HU & 11.0 & 10.9 & 11.0 & 10.9 & 10.9 & 10.8 & 10.8 & 10.7 \\
\hline MT & 6.8 & 6.6 & 6.5 & 6.4 & 6.3 & 6.3 & 6.4 & 6.4 \\
\hline NL & 4.4 & 4.2 & 4.1 & 4.3 & 4.4 & 4.5 & 4.8 & 4.9 \\
\hline AT & 4.2 & 4.2 & 3.9 & 3.7 & 3.7 & 3.9 & 4.1 & 4.0 \\
\hline PL & 9.6 & 9.6 & 9.6 & 9.7 & 9.7 & 9.8 & 9.9 & 10.0 \\
\hline PT & $12.3 \mathrm{e}$ & 12.6 & 12.5 & 12.6 & 12.6 & 12.8 & 13.0 & 13.2 \\
\hline RO & 7.4 & 7.3 & 7.3 & 7.5 & 7.5 & 7.7 & 7.3 & 7.3 \\
\hline SI & 7.7 & 7.9 & 8.0 & 8.1 & 8.0 & 8.2 & 8.2 & 8.2 \\
\hline SK & 14.0 & 13.3 & 13.3 & 13.3 & 13.4 & 13.4 & 13.5 & 13.5 \\
\hline FI & 8.1 & 7.8 & 7.8 & 7.7 & 7.7 & 7.6 & 7.5 & 7.4 \\
\hline SE & 7.8 & 7.7 & 7.4 & 7.4 & 7.4 & 7.3 & 7.5 & 7.4 \\
\hline UK & 7.7 & 7.9 & 8.0 & 8.1 & 8.3 & 8.3 & : & : \\
\hline
\end{tabular}

Source: EUROSTAT, 5/2012 - $6^{\text {th }}$ January 2012, Brussels

Note: The euro area (EA-17) consists of Belgium, Germany, Estonia, Ireland, Greece, Spain, France, Italy, Cyprus, Luxembourg, Malta, the Netherlands, Austria, Portugal, Slovenia, Slovakia and Finland. The EU-27 includes Belgium (BE), Bulgaria (BG), the Czech Republic (CZ), Denmark (DK), Germany (DE), Estonia (EE), Ireland (IE), Greece (EL), Spain (ES), France (FR), Italy (IT), Cyprus (CY), Latvia (LV), Lithuania (LT), Luxembourg (LU), Hungary (HU), Malta (MT), the Netherlands (NL), Austria (AT), Poland (PL), Portugal (PT), Romania (RO), Slovenia (SI), Slovakia (SK), Finland (FI), Sweden (SE) and the United Kingdom (UK).

Eurostat defines unemployed persons as persons aged 15 to 74 who:

- are without work;

- are available to start work within the next two weeks;

- and have actively sought employment at some time during the previous four weeks.

The unemployment rate is the number of people unemployed as a percentage of the labour force. The labour force is the total number of people employed plus unemployed.

Monthly unemployment and employment series are calculated first at the level of four categories for each Member State (males and females 15-24 years, males and females 25-74 years). These series are then seasonally adjusted and all the national and European aggregates are calculated. 
Table 2 (3). Seasonally adjusted youth unemployment rates (\%)

\begin{tabular}{|c|c|c|c|c|c|c|c|c|c|c|c|c|}
\hline & \multicolumn{4}{|c|}{ Youth (under 25's) } & \multicolumn{4}{|c|}{ Males } & \multicolumn{4}{|c|}{ Females } \\
\hline & $\begin{array}{l}\text { Nov- } \\
2010\end{array}$ & $\begin{array}{c}\text { Sep- } \\
201 \\
1\end{array}$ & $\begin{array}{c}\text { Oct- } \\
201 \\
1\end{array}$ & $\begin{array}{c}\text { Nov } \\
- \\
201 \\
1\end{array}$ & $\begin{array}{l}\text { Nov- } \\
2010\end{array}$ & $\begin{array}{c}\text { Sep- } \\
201 \\
1\end{array}$ & $\begin{array}{c}\text { Oct- } \\
201 \\
1\end{array}$ & $\begin{array}{c}\text { Nov } \\
- \\
201 \\
1\end{array}$ & $\begin{array}{l}\text { Nov- } \\
2010\end{array}$ & $\begin{array}{c}\text { Sep- } \\
201 \\
1\end{array}$ & $\begin{array}{c}\text { Oct- } \\
201 \\
1\end{array}$ & $\begin{array}{c}\text { Nov } \\
- \\
201 \\
1\end{array}$ \\
\hline $\begin{array}{c}\text { EA1 } \\
7\end{array}$ & 20.6 & 21.1 & 21.4 & 21.7 & 9.8 & 9.9 & 10.1 & 10.0 & 10.3 & 10.6 & 10.6 & 10.7 \\
\hline $\begin{array}{c}\text { EU2 } \\
7\end{array}$ & 21.0 & 21.8 & 22.0 & 22.3 & 9.5 & 9.6 & 9.7 & 9.7 & 9.7 & 9.9 & 9.9 & 10.0 \\
\hline BE & 21.4 & 21.0 & 21.1 & 21.1 & 7.8 & 7.3 & 7.3 & 7.2 & 8.1 & 7.4 & 7.3 & 7.3 \\
\hline BG & 25.8 & 24.7 & 24.8 & 25.6 & 12.3 & 11.9 & 11.8 & 11.9 & 10.6 & 9.7 & 9.8 & 9.9 \\
\hline $\mathrm{CZ}$ & 17.1 & 18.1 & 18.6 & 19.0 & 6.0 & 5.7 & 5.8 & 5.9 & 8.2 & 7.6 & 7.7 & 7.7 \\
\hline DK & 14.0 & 15.0 & 14.9 & 14.9 & 7.9 & 7.5 & 7.6 & 7.7 & 7.5 & 7.8 & 7.9 & 7.9 \\
\hline DE & 9.1 & 8.5 & 8.3 & 8.1 & 7.0 & 5.8 & 5.7 & 5.5 & 6.3 & 5.7 & 5.6 & 5.5 \\
\hline $\mathbf{E E}$ & 25.7 & 21.8 & : & : & 15.7 & 11.4 & : & : & 13.3 & 11.1 & : & : \\
\hline IE & 29.1 & 29.2 & 29.2 & 29.3 & 17.5 & 17.3 & 17.3 & 17.2 & 10.3 & 11.1 & 11.2 & 11.4 \\
\hline EL & 36.3 & 46.6 & : & : & 11.4 & 16.3 & 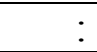 & : & 17.7 & 22.3 & : & : \\
\hline ES & 43.0 & 48.3 & 49.0 & 49.6 & 20.1 & 22.1 & 22.5 & 22.8 & 20.8 & 22.9 & 23.0 & 23.0 \\
\hline FR & 23.0 & 22.8 & 23.3 & 23.8 & 9.0 & 9.1 & 9.2 & 9.3 & 10.3 & 10.2 & 10.3 & 10.3 \\
\hline IT & 28.4 & 29.2 & 29.2 & 30.1 & 7.2 & 7.4 & 7.9 & 7.6 & 9.4 & 9.6 & 9.3 & 9.9 \\
\hline $\mathbf{C Y}$ & 15.3 & 23.1 & : & : & 5.7 & 8.4 & 8.8 & 9.2 & 6.4 & 8.5 & 8.8 & 9.1 \\
\hline $\mathbf{L V}$ & 30.8 & 29.9 & : & : & 18.7 & 16.8 & $\bar{\theta}$ & : & 15.2 & 12.7 & : & : \\
\hline LT & 33.9 & 31.1 & $:$ & : & 20.0 & 17.5 & $:$ & : & 14.7 & 13.1 & : & : \\
\hline $\mathbf{L U}$ & 14.9 & 15.3 & 14.4 & 14.7 & 3.6 & 3.7 & 3.7 & 3.7 & 6.1 & 6.5 & 6.3 & 6.4 \\
\hline HU & 25.4 & 26.1 & 26.1 & 25.9 & 11.3 & 10.9 & 10.9 & 10.7 & 10.7 & 10.7 & 10.7 & 10.7 \\
\hline MT & 13.5 & 13.9 & 14.1 & 14.3 & 6.8 & 6.0 & 6.0 & 6.1 & 6.8 & 7.0 & 7.0 & 7.1 \\
\hline $\mathbf{N L}$ & 8.4 & 8.0 & 8.2 & 8.6 & 4.3 & 4.5 & 4.7 & 4.9 & 4.5 & 4.6 & 4.8 & 5.0 \\
\hline AT & 8.1 & 7.5 & 8.7 & 8.3 & 4.2 & 3.8 & 4.0 & 3.8 & 4.3 & 4.0 & 4.1 & 4.2 \\
\hline $\mathbf{P L}$ & 23.8 & 26.4 & 27.2 & 27.8 & 9.2 & 8.9 & 9.0 & 9.1 & 10.0 & 10.9 & 11.0 & 11.0 \\
\hline PT & $\begin{array}{r}27.2 \\
\mathrm{e}\end{array}$ & 30.1 & 30.4 & 30.7 & $\begin{array}{r}12.1 \\
\mathrm{e}\end{array}$ & 12.5 & 12.6 & 12.9 & $\begin{array}{r}12.6 \\
\mathrm{e}\end{array}$ & 13.1 & 13.3 & 13.5 \\
\hline RO & 23.3 & 23.4 & $:$ & : & 8.0 & 8.2 & 8.1 & 7.7 & 6.5 & 7.0 & 6.4 & 6.7 \\
\hline SI & 14.5 & 15.2 & : & : & 7.9 & 8.2 & 8.3 & 8.4 & 7.4 & 8.1 & 8.0 & 8.0 \\
\hline SK & 33.3 & 33.9 & 34.5 & 35.1 & 14.0 & 13.4 & 13.5 & 13.6 & 14.1 & 13.4 & 13.4 & 13.3 \\
\hline FI & 20.8 & 19.9 & 19.7 & 19.6 & 8.6 & 8.3 & 8.2 & 8.1 & 7.5 & 6.9 & 6.8 & 6.7 \\
\hline SE & 22.6 & 22.2 & 22.3 & 23.2 & 7.9 & 7.3 & 7.6 & 7.5 & 7.7 & 7.2 & 7.3 & 7.4 \\
\hline UK & 20.2 & 22.0 & & : & 8.4 & 9.0 & & : & 7.0 & 7.5 & : & : \\
\hline
\end{tabular}

Source: EUROSTAT, 5/2012 - $6^{\text {th }}$ January 2012, Brussels

The world market demands have been less and narrow since 2008, when the world economic crisis started, which stimulated the continuous increasing trends of the youth unemployment rate in the EU-27 (see Table-3). In highly developed economies including EU-27, the youth unemployment trend has increased since 2000 from $13,5 \%$ to $18,2 \%$ in 2010 , because labour force market demands decreased and in general the youth human resources were less skilled and educated for jobs offered by companies. (ILO, 2010a; ILO, 2010b). The economic growth is estimated only at the end of 2013 or at the beginning of 2014, when probably the youth unemployment rate can decrease. 
There are strong correlations among the unemployment rates, GDP per capita and AIC per capita, foreign trade, balance of EU-27 current account with employment conditions, which can be described based on the SWOT analysis, which are as follows:

\section{The employment based on SWOT analysis in EU-27}

\section{Strengths:}

- Mostly before the world economic crisis the increasing trend of employment strengthens the purchase power standard of consumers based on the extending investments and creating jobs.

- The export oriented economic policy helps to extend market positions of EU-27 on the world market, to which foreign economic cooperation of Hungary with South Korea and India can contribute, as successful examples (see in detailed in Neszmélyi, 2001; Neszmélyi, et al, 2007).

- The human resource national policy stimulates transnational corporations and large companies to use educational activity for improving and increasing efficiency and skill level of employees.

- Decrease the poverty at social level.

\section{Weaknesses:}

- $\quad$ The wholly employment decreases the efficiency of human resources.

- Under educated and skilled workers in employment are unfavourable for EU-27 to obtain competitiveness on the market.

- The highly level employment conditions make affects on increasing the inflation rate and decreasing PPS per capita.

\section{Opportunities:}

- Influences of the trans-national corporations (TNCS) on increasing and fixing favourable employment conditions.

- $\quad$ TNCs have positive influences on the creating diversification of the economic structure and labour force in EU member states to become more flexible demands of the world economy and the world market. Also the TNCs realise the FDI (foreign direct investment) to increase the employment level in EU member states. The FDI can strengthen the employment conditions by setting up the vertically integrated product channel to use high-tech and ensuring products to supply single market in EU (see in detailed in Zbida Adel et. Al., 2011; Zsarnóczai, 2003 in case of Denmark; Zsarnóczai, J. S., 1996 in case of Germany).

\section{Threats:}

- Negative influence of the world economy, sharply energy increase on activities of firm in field of human resource management less market demands for labour forces.

- From point of view of input: cheaper foreign labour force can also press the EU-27 domestic labour force market out of the labour market and employment possibilities. The cheaper foreign labour force can inflow from out of the EU, but also the free labour force flow among EU member states can result restructure of employees in each member state.

- The foreign direct investment (FDI) can be favourable for the domestic economic growth in EU-27, but sometimes this FDI can focus on the increasing foreign human resources instead of domestic-national workers-employees (WEF = World Economic Forum, 2010).

- The global warming resulted by the gas emission of human activities extends dessert areas with considerable low level of density in EU-27, mostly in Mediterranean member states. This strengthens and results in unfavourable separation of human resources. Also this 
global warming resulted in increasing illness and considerable damages for human resources form point of view of health care.

Also the decreasing trends of population in whole EU will lead to restructure the employment conditions, because the foreign workers will increase and can be dominate on labour force market of EU either in their number or their skilled level even for the near future.

\section{Conclusions}

The high level of unemployment rate can contribute to increasing the labour efficiency at the trans-national corporation (TNC) level, but this can not solve the economic and social difficulties concerning the narrowing market positions for companies and decreasing life standard for wider social groups and the extending poverty at social level (Laskai - Zéman, 2013).

There is a considerable world-wide side competition among new emerging economies and former developed economies to obtain more share of the world market. Also the competition became stronger among economies and firms, transnational corporations and small and medium scale enterprises in field of developing and obtaining innovation and $R \& D$ (Research\&Development) process. The cheaper labour force can not ensure long-term competition on the world market.

Increasing population of the world economy can grow the qualified labour force demands based on the innovation development and unemployment rate on the world market, finally the poorness. Also this increasing population results the increasing energy consumption and price level of energy, therefore the consumption structure changes at house hold or family units from dominant food consumption to dominant energy consumption, also less highly value added and developed product-consumption. In this case the narrow world market provides less market positions for the EU-exporters resulting in decreasing employment, first youth employment in EU-27. The higher level of youth unemployment rate resulted in less number of weddings and borning of children in EU-27, which leads to more pension difficulty in the future. Also in spite that the high level of unemployment can decrease the inflation growing trends, the less level of employment decreases PPS per capita finally selling products on the market.

In consequence of the increasing population in the world economy, the consumption increases at level of national economics, firms and house holds or family units, which can leads to increasing state debt based on the emerging spiral later on with decreasing consumption of population. Also the increasing state debt results heavy personal and firm-profit tax burdens on tax payers, as named consumers, therefore the production and consumption decrease and the producers should decrease the export of the EU-27.

The regional development can be implemented by through of decreasing gap among developed levels of different regions based on the increasing employment level. The governments should also help the small and medium enterprises (SMEs) to create better and more favourable work separation among the SMEs and corporations owning and using high-tech and researchdevelopment (R\&D) based on education and financial supports.

The sustainable employment and economic conditions of EU-27 need for increasing investment activities to meet market demand, to increase highly value added products and to increase the AIC of population and strengthening the PPS of population of the EU-27based on the extending employment rate. The best way is to increase the highly value added products within vertically 
integrated product channel (see in detailed in Zsarnóczai, J. S., 2000 in case of Finland; Zsarnóczai, J. S., 2003 in case of Denmark). The successful moderately economic growth by increasing the employment can decrease the poverty at social level.

\section{Acknowledgement}

Research was supported by the project TÁMOP 4.21.B-11/2/KMR-2011-0003.

\section{References}

1. EUROSTAT, (2012), Euro area unemployment rate at 10,3\%. 5/2012 - $6^{\text {th }}$, January, 2012

2. EUROSTAT $(2011,2012,2013)$ December, Brussels

3. ILO (2010a), Global employment trends for youth, August, 2010 - Special issue on the impact of global economic crisis on youth, Geneva

4. ILO (2010b), Trends Econometric Models, October, 2010, Geneva

5. ILO (2011): Global employment trends - 2011, Geneva, Switzerland ISBN 978-92-2124546-9

6. IMF (2010a), Regional Economic Outlook: Middle East and Central Asia, in the World Economy and Financial Surveys, Washington, DC, May 2010 http://dx.doi.org/10.5089/9781589069206.086

7. IMF (2010b), World Economic Outlook: Recovery, risk and rebalancing, Washington, DC, October 2010 http://dx.doi.org/10.5089/9781589069596.081

8. Káposzta J. (1998): Területi gazdaságtan, GATE, Gödöllő

9. Káposzta, J. - Nagy, H - Villányi, L. (2008): Enlargement processes in the European Union and the sustainability indicators of Bulgaria and Romania, In: Szücs István, Zsarnóczai J Sándor, Molnár József, Benet Iván, Szabó Gábor, Szabó Lajos, Villányi László, Hajós László, Lehota József, Farkasné Fekete Mária, Kanizsay Endre, Khaled Karim, Mrs Mária Kadlecíková, Magdalena Hrabankova, Alvaro Standardi, Francis Nwonwu, Carlos Noéme (szerk.), Economics of Sustainable Agriculture, Scientific Book Series, Gödöllő: Szent István University, 2008. pp. 79-103, ISBN: 978-963-269-016-2; 9639483699

10. Laskai, A. - Zéman, Z. (2013): Az üzleti terv mint pénzügyi controlling instrumentum nemzetközi összehasonlításban. (The business plan, as financial controlling instrumentum in the international compare), pp. 16-22, Controller Info. Scientific Journal, Copy \& Consulting Kft, 1. Number, 2013. ISSN 2063-9309

11. Nagy, H.- Káposzta, J. (2010): Social and regional aspects of the structural and Cohesion Funds in the new EU member states between 2007-2013, In: Peter Bielik (ed.), Economics, Social Policy and Citizenship in the European Union - Evidence of V4 Countries and Perspectives for Ukraine, Nitra: Slovak University of Agriculture, Faculty of European Studies and Regional Development, 2010. pp. 148-167, ISBN: 978-80-552$0448-2$

12. Neszmélyi, Gy. - Kusai, S. - Pap, L. (2007): India - Az új kihívás és esély (India, new challenge and chance), Külügyi Szemle (Foreign Affairs Review) 2007. VI. évf. 1. sz., pp. $122-136$

13. Neszmélyi, Gy. (2001): The Prospective of the Economic Cooperation between Hungary and the Republic of Korea Focusing on the Food and Agricultural Sector. East European Studies (Republic of Korea) (ISSN: 1229-442X) Vol 10 (1)/2001, pp. 237-253.

14. WEF (World Economic Forum, 2010): Global competitiveness report, 2010-2011.

15. Zbida Adel - Guth, L. - Zsarnóczai, J. S. (2011), Külföldi közvetlen tőkebefektetések hatása a hazai regionális fejlesztésre (Influences of foreign direct investments on national 
regional development), Polgári Szemle, Gazdasági és Társadalmi Folyóirat. ISSN 17866553: (7. évfolyam, 1. szám) pp. 63-76.

16. Zsarnóczai, J. S. (1996) Németország mezőgazdasági helyzete az 1990-es évek első felében. (Agricultural condtions of Germany in second half of 1990-ies). Statisztikai Szemle. KSH havi folyóirata. Statistical Review, 74. year, No: 3, pp. 230-238. ISSN 0039 0690,

17. Zsarnóczai, J. S. (2000) Jövedelemviszonyok és támogatási rendszer a finn mezőgazdaságban. (Income conditions and support system in the Finnish agriculture). Gazdálkodás, havi folyóirat. 44. Évfolyam, 3. Szám. Agricultural Economy, agricultural scientific monthly bulletin 44. Year, No: 3. Pp. 67-73. HU ISSN 0046-5518

18. Zsarnóczai, J. S. (2003) Szövetkezeti szerveződés Dániában a XXI. század elején. (Organisation of co-opratives in Denmark at the beginning of the 21 st century). Gazdálkodás, havi folyóirat. 47. Évfolyam, 1. Szám. Agricultural Economy, agricultural scientific monthly bulletin 47. Year, No: 1. Pp. 71-74. HU ISSN 0046-5518 